\title{
Exceptions and Exclusions: The Right to Informed Consent for Medical Treatment of People with Psychosocial Disabilities in Europe
}

Citation for published version (APA):

Waddington, L., \& McSherry, B. (2016). Exceptions and Exclusions: The Right to Informed Consent for Medical Treatment of People with Psychosocial Disabilities in Europe. European Journal of Health Law, 23(3), 279 - 304. https://doi.org/10.1163/15718093-12341389

Document status and date:

Published: 01/01/2016

DOI:

10.1163/15718093-12341389

Document Version:

Publisher's PDF, also known as Version of record

Document license:

Taverne

Please check the document version of this publication:

- A submitted manuscript is the version of the article upon submission and before peer-review. There can be important differences between the submitted version and the official published version of record.

People interested in the research are advised to contact the author for the final version of the publication, or visit the DOI to the publisher's website.

- The final author version and the galley proof are versions of the publication after peer review.

- The final published version features the final layout of the paper including the volume, issue and page numbers.

Link to publication

\footnotetext{
General rights rights.

- You may freely distribute the URL identifying the publication in the public portal. please follow below link for the End User Agreement:

www.umlib.nl/taverne-license

Take down policy

If you believe that this document breaches copyright please contact us at:

repository@maastrichtuniversity.nl

providing details and we will investigate your claim.
}

Copyright and moral rights for the publications made accessible in the public portal are retained by the authors and/or other copyright owners and it is a condition of accessing publications that users recognise and abide by the legal requirements associated with these

- Users may download and print one copy of any publication from the public portal for the purpose of private study or research.

- You may not further distribute the material or use it for any profit-making activity or commercial gain

If the publication is distributed under the terms of Article $25 \mathrm{fa}$ of the Dutch Copyright Act, indicated by the "Taverne" license above, 


\title{
Exceptions and Exclusions: The Right to Informed Consent for Medical Treatment of People with Psychosocial Disabilities in Europe
}

\author{
Lisa Waddington
}

Professor of European Disability Law, Maastricht University, Maastricht, The Netherlands

\section{Bernadette McSherry}

Adjunct Professor of Law, University of Melbourne Law School; Faculty of Law, Monash University; Australia; Foundation Director, Melbourne Social Equity Institute, University of Melbourne, Australia

\begin{abstract}
This article examines the relevant international law relating to informed consent to treatment for individuals with psychosocial disabilities and reflects on the protection offered in this respect by the European Convention on Human Rights (ECHR) and the Council of Europe Convention on Human Rights and Biomedicine. The article argues that while the UN Convention on the Rights of Persons with Disabilities is beginning to influence case law of the European Court of Human Rights, only 'weak' protection has been afforded to people with psychosocial disabilities by the ECHR and the Court in relation to informed consent for medical treatment.
\end{abstract}

\section{Keywords}

European Convention on Human Rights (ECHR) - psychosocial disabilities - informed consent - medical treatment - human rights - Convention on the Rights of Persons with Disabilities - legal capacity

* This article was largely written whilst Professor Waddington was on research sabbatical at Melbourne University. The author is grateful to the Melbourne Social Equity Institute and Melbourne University School of Law for hosting her whilst on sabbatical, and to the Melbourne University School of Law for providing financial support through the International Research Visitor's Scheme. 
For those with psychosocial disabilities, the United Nations' Convention on the Rights of Persons with Disabilities (CRPD) has been hailed as signalling a 'new era' in terms of limitations on, if not the abolition of, compulsory detention and treatment. ${ }^{1}$ In Europe, the CRPD is already being considered by the European Court of Human Rights (the Court or ECtHRs) which interprets and applies the European Convention on Human Rights (ECHR), and the CRPD has been referred to in a number of judgments. This is in spite of the fact that the Council of Europe, unlike the European Union, has not formally become a party to the CRPD.

Whilst the ECHR does not explicitly address informed consent for medical treatment, the Court has applied various provisions of the ECHR in the context of involuntary medical treatment. The Court has considered, in particular, Article 3, which provides that no one shall be subject to 'inhuman and degrading treatment', and Article 8, which protects the right, inter alia, to private life in this context. As a result, individuals in Europe benefit from protection under a human rights convention which requires, in principle, informed consent for any medical treatment.

This article begins by outlining the relevant international law relating to informed consent to treatment, with particular attention paid to the debates about the CRPD's interpretation in relation to individuals with psychosocial disabilities. The article then turns to examining the protection provided under the ECHR and the Council of Europe Convention on Human Rights and Biomedicine, before reaching the conclusion that only 'weak' protection has been afforded to people with psychosocial disabilities in relation to informed consent to medical treatment.

1 T. Minkowitz, "The United Nations Convention on the Rights of Persons with Disabilities and the Right to be Free from Nonconsensual Psychiatric Interventions', Syracuse Journal of International Law and Commerce 34(2) (2007) 404-428, 427. See also United Nations News Centre, 2006, 'Lauding Disability Convention as 'Dawn of a New Era', Un Urges Speedy Ratification', 13 December. www.un.org/apps/news/story.asp?NewsID=20975\#.VY-Of_mqqko, retrieved 28 June 2015. For an overview of the debate concerning abolition of laws enabling compulsory mental health treatment versus reform, see P. Gooding, 'Supported DecisionMaking: A Rights Based Disability Concept and Its Implications for Mental Health Law', Psychiatry, Psychology and Law 2o(3) (2013) 431-451; B. McSherry, 'Mental Health Laws: Where to from Here?', Monash University Law Review 40(1) (2014) 175-197; B. McSherry and K. Wilson, 'The concept of capacity in Australian mental health law: Going in the wrong direction?', International Journal of Law and Psychiatry 40 (2015) 60-69. 
The right to health has been recognised and developed within various human rights treaties and includes the right to access different elements of healthcare and related services. In this respect Jennifer Sellin has stated: 'the international right to health does not entail a right for individuals to be healthy, but it encompasses a number of freedoms and entitlements to enable individuals to attain the highest standard of health possible.'

Article 12 of the International Covenant on Economic, Social and Cultural Rights sets out the general right to health. ${ }^{3}$ However, various human rights conventions, including the Convention on the Elimination of All Forms of Discrimination against Women, the Convention on the Elimination of All Forms of Racial Discrimination, and the Convention on the Rights of the Child contain health-related rights, and seek to tailor these to the particular needs of the covered groups. In the disability context, the CRPD seeks to do the same. The CRPD addresses health in Article 25 which provides: 'States Parties recognize that persons with disabilities have the right to the enjoyment of the highest attainable standard of health without discrimination on the basis of disability'. Para. (d) of the Article further specifies that State Parties shall: " $[\mathrm{r}]$ equire health professionals to provide care of the same quality to persons with disabilities as to others, including on the basis of free and informed consent....

Articles 12 and 25 are supplemented by Article 15, which provides that '[n]o one shall be subjected to torture or to cruel, inhuman or degrading treatment or punishment' and Article 17, which provides that '[e]very person with disabilities has a right to respect for his or her physical and mental integrity on an equal basis with others. ${ }^{4}$ An individual's integrity is violated when he or she is subject to enforced treatment. ${ }^{5}$

2 J. Sellin, Access to Medicine, The Interface between Patents and Human Rights. Does One Size Fit All? (Cambridge: Intersentia, 2014) p. 82.

3 See also Committee on Economic, Social and Cultural Rights, General Comment No 5, Persons with disabilities (11th sess, 1994), UN Doc E/1995/22 p. 19 (1995), reprinted in Compilation of General Comments and General Recommendations Adopted by Human Rights Treaty Bodies, UN Doc. HRI/GEN/1/Rev.6 p. 24 (2003); and Committee on Economic, Social and Cultural Rights, General Comment 14, The right to the highest attainable standard of health (22nd sess, 2000), UN Doc. E/C.12/2000/4 (2000), reprinted in Compilation of General Comments and General Recommendations Adopted by Human Rights Treaty Bodies, UN Doc. HRI/GEN/1/ Rev.6 p. 85 (2003).

4 For a discussion of Article $17 \mathrm{CRPD}$, its drafting history, and its failure to explicitly prohibit forced medical treatment, see ibid., 769-770.

5 For a discussion of the relevance of Articles 15, 17 and 25 CRPD to involuntary treatment, see European Union Agency for Fundamental Rights, Involuntary placement and involuntary 
Anna Bruce notes that the issue of whether health interventions could ever be performed without the recipient's consent was one of the most controversial issues during the negotiations of the Convention. ${ }^{6}$ Some guidance on this issue has now been provided by General Comment No 1 of the CRPD Committee on Article 12 which deals with Equal Recognition before the Law. ${ }^{7}$

While the General Comment focuses on Article 12, it also addresses the issue of informed consent under Article 25. It states:

The right to enjoyment of the highest attainable standard of health (art. 25) includes the right to health care on the basis of free and informed consent. States parties have an obligation to require all health and medical professionals (including psychiatric professionals) to obtain the free and informed consent of persons with disabilities prior to any treatment. In conjunction with the right to legal capacity on an equal basis with others, States parties have an obligation not to permit substitute decision-makers to provide consent on behalf of persons with disabilities. All health and medical personnel should ensure appropriate consultation that directly engages the person with disabilities. They should also ensure, to the best of their ability, that assistants or support persons do not substitute or have undue influence over the decisions of persons with disabilities. $^{8}$

General Comment No 1 certainly appears to suggest that all people, irrespective of their ability or disability, must give individual consent for medical treatment and, whilst supported decision-making is permissible for those people who need it, substituted decision-making will always be regarded as incompatible with the Convention. This is reflected in Peter Bartlett's observation that 'the CRPD appears to proceed on the basis that disability cannot be used as a factor in determining whether compulsion may be imposed' ${ }^{9}$

Article 12(2) of the CRPD recognises that 'persons with disabilities enjoy legal capacity on an equal basis with others in all aspects of life' and Article

treatment of persons with mental health problems (Luxembourg: Publications Office of the European Union, 2012) pp. 22-23.

6 A. Bruce, Which Entitlements and for Whom? The Convention on the Rights of Persons with Disabilities and its Ideological Antecedents (Lund: Lund University Publications, 2014) p. 160.

7 Committee on the Rights of Persons with Disabilities, General Comment No 1, Article 12: Equal recognition before the law (11th sess, 2014), UN Doc. CRPD/C/GC/1 (2014).

8 Ibid., para. 41.

9 P. Bartlett, "The United Nations Convention on the Rights of Person with Disabilities and Mental Health Law', Modern Law Review 75(5) (2012) 752-778, 753 . 
12(3) refers to exercising legal capacity. In the past, legal capacity has generally been conflated with mental capacity which the UN CRPD Committee defines as 'the decision-making skills of a person'. ${ }^{10}$ The Committee states:

the concepts of mental and legal capacity have been conflated so that where an individual is thought to have impaired decision-making skills, often because of a cognitive or psychosocial disability, her legal capacity to make a particular decision is removed ... an individual's disability and or decision-making skills are accepted as a legitimate basis for denying her legal capacity and lowering her status before the law. Article 12 does not permit this discriminatory denial of legal capacity... ${ }^{11}$

Laws that enable involuntary treatment on the basis of a loss of decision-making capacity on this view are therefore discriminatory. Mental capacity should no longer be intrinsically linked to legal capacity. In Genevra Richardson's words: 'in its purest form there is no point beyond which legal capacity is lost. There is no binary divide..$^{2}$ On this basis, some authors have argued that there can be no exceptions to legal capacity and thus no justifications for substituted decision-making regimes. ${ }^{13}$ In comparison, others have argued that some form of substituted decision-making based on assessments of the ability to make decisions is necessary and permissible under Article $12 .{ }^{14}$ Rosemary Kayess and Phillip French, for example, state that the failure to acknowledge real differences in abilities in the CRPD leads to superficial equality and they argue this is most evident in Article 12, ${ }^{15}$ 'which border[s] on a complete denial of the instrumental limitations associated with cognitive impairments.' ${ }^{16}$

$10 \quad$ Ibid., para. 12.

11 Ibid., para. 13.

12 G. Richardson, 'Mental Capacity in the Shadow of Suicide: What Can the Law Do?', International Journal of Law in Context 9(1) (2013) 87-105, 92.

13 See, for example, T. Minkowitz, 'Abolishing Mental Health Laws to Comply with the Convention on the Rights of Persons with Disabilities', in B. McSherry and P. Weller (eds.), Rethinking Rights-Based Mental Health Laws (Oxford, Hart Publishing, 2010) pp. 151-177.

14 See, for example, S. Callaghan and C. Ryan, 'Is There a Future for Involuntary Treatment in Rights-based Mental Health Law?', Psychiatry, Psychology and Law 21(5) (2014) 747-766; J. Dawson, 'A realistic approach to assessing mental health laws' compliance with the UNCRPD', Journal of Law and Psychiatry 40 (2015) 70-79.

15 As well as Article 17.

16 R. Kayess and P. French, 'Out of darkness into light? Introducing the Convention on the Rights of Persons with Disabilities', Human Rights Law Review 8(1) (2008) 1-34, 7 (fn. 31). 
Joseph Dute, in a recent editorial in the European Journal of Health Law, ${ }^{17}$ expands on this criticism in the context of General Comment No 1 and substitute decision-making in the context of medical treatment. He notes the interpretation of the CRPD Committee that substituted decision making is not compatible with the Convention, but criticises this as 'a step too far',18 arguing that [t]he Committee 'has lost sight of reality'.19 $\mathrm{He}$ argues that to abolish substituted decision-making in its entirety in the context of medical treatment would be 'unworkable'20 and the Committee has failed to recognise that some individuals are simply unable to take a decision regarding their own medical treatment, even with extensive support. He also argues that such an approach would undermine the possibility to 'protect people who are in need of care'21 and substituted decision-making can facilitate suitable medical treatment and care.

However, Dute does recognise that forced admission and treatment to a psychiatric institution, which is the subject of much of the case law considered in this paper, whilst allowing for therapeutic interventions, does run the risk of being discriminatory as it is based the subjective concept of 'dangerousness.' ${ }^{22}$

In relation to those with psychosocial disabilities, Melvyn Colin Freeman and seven colleagues recently published a 'personal view' of the General Comment in the Lancet Psychiatry. ${ }^{23}$ They argue that the General Comment 'threatens to undermine critical rights for persons with mental disabilities, including the enjoyment of the highest attainable standard of health, access to justice, the right to liberty, and the right to life. ${ }^{24}$ In addition, they state that '[s]tigma and discrimination might also increase.. ${ }^{25}$

17 J. Dute, Editorial 'Should Substituted Decision-making Be Abolished?', European Journal of Heath Law 22 (2015) 315-320.

$18 \quad$ Ibid., 318.

19 Ibid.

20 Ibid.

$21 \quad$ Ibid.

22 Ibid., 319. Dute does not refer to the 'subjectiveness' of the concept of dangerous — this attribution has been assigned to the concept by the present authors.

23 M.C. Freeman, K. Kolappa, J.M. Caldas de Almeida, A. Kleinman, N. Makhashvili, S. Phakathi, B. Saraceno, and G. Thornicroft, 'Personal View 'Reversing hard won victories in the name of human rights: a critique of the General Comment on Article 12 of the UN Convention on the Rights of Persons with Disabilities', Lancet Psychiatry 2(9) (2015) 844-850.

24 Ibid., 844.

25 Ibid. 
Whilst recognising that legal capacity should always be assumed and safeguards should be provided, they argue, like Dute, that informed consent for medical treatment is not always possible and to deny individuals medical treatment on the basis that they are unable to consent would violate a number of other human rights protected in the Convention. Freeman and colleagues put the problems with the General Comment down to the 'absence of clinical experts on the Committee, ${ }^{26}$ the failure to consult clinicians when drafting the Comment, and the failure of the Committee to take note of users of psychiatric healthcare who support substitute decision-making in the context of medical treatment in some circumstances. Unlike Dute, Freeman and colleagues acknowledge the wide involvement of service users (including persons with psychosocial disabilities) in drafting the CRPD and the General Comment, and the support many users expressed for the abolition of involuntary treatment and detention, but argue that service users and others expressing a contrary view were not adequately heard.

Other scholars have been less critical of the CRPD and General Comment No 1, and, in some cases, spoken out in praise of them. Jill Stavert, writing in the Scottish context, argues that the General Comment and Article 12 of the CRPD can provide the stimulus to review existing legal capacity regimes and provisions concerning consent for medical treatment by persons with psychosocial disabilities, with a view to providing greater protection of human rights and respect for individual wishes. ${ }^{27}$ Lucy Series similarly praises the CRPD for creating 'an opening for discussions' and 'new tools for approaching these discussions through its powerful focus on equality, autonomy and the external determinants of disablement, vulnerability and risk. ${ }^{28}$ She argues that the most important contribution of the CRPD is to require that persons with disabilities are actively involved in deliberations on laws and policies which concern them, rather than having their decisions 'being delegated to the very "experts" they so often empower. ${ }^{29}$

Eilionoir Flynn and Anna Arstein-Kerslake, writing about the broader issue of legal recognition of 'personhood' and Article 12 of the CRPD, argue that

\footnotetext{
$26 \quad$ Ibid., 848.

27 J. Stavert, 'The Exercise of Legal Capacity, Supported Decision-Making and Scotland's Mental Health and Incapacity Legislation: Working with CRPD Challenges', Laws 4 (2015), 296-313.

28 L. Series, 'Relationships, autonomy and legal capacity: Mental capacity an support paradigms', International Journal of Law and Psychiatry 40 (2015), 80-91, 89.

$29 \quad$ Ibid.
} 
personhood should be separated from cognition. ${ }^{30}$ They argue that Article 12 establishes that legal capacity is universal, and always remains with the individual. This imposes an obligation on States Parties to eliminate substituted decision-making making regimes in their entirety, recognise the diversity of ability to make decisions, and provide a continuum of support to ensure legal capacity.

These various contributions reflect the ongoing nature of the debate amongst scholars in the field on the need for informed consent and the role (if any) for substitute decision-making. ${ }^{31}$ Suffice to say that the purist interpretation of the CRPD poses a significant challenge to those State Parties which have ratified the Convention including States in Europe, where substituted decision-making by guardians or other legally appointed or recognised representatives with regard to medical treatment is still common place.

3

\section{The European Convention on Human Rights and Involuntary Medical Treatment}

Whilst the $\mathrm{ECHR}^{32}$ does not address the issue of consent to medical treatment specifically, the European Court of Human Rights has relied on Article 3 of the

30 E. Flynn and A. Arstein-Kerslake, 'Legislating personhood: Realising the right to support in exercising legal capacity', International Journal of Law in Context 10(1) (2014), 81-104. See also E. Flynn and A. Arstein-Kerslake, 'The Support Model of Legal Capacity: Fact, Fiction, or Fantasy?', Berkeley Journal of International Law 32(1) (2014), 124-143, in which the authors set out their views on a 'plausible' legal framework for a regime of substituted decision-making which could replace existing regimes of substituted decision-making.

$31 \quad$ See special edition of the International Journal of Law and Psychiatry 40 (2015).

32 In addition to the ECHR, there are a number of non-binding, or soft law, instruments addressing this field which have been adopted by the Council of Europe. These include Council of Europe Recommendation No. REC (2004) 10 of the Committee of Ministers to Member States Concerning the Protection of the Human Rights and Dignity of Persons with Mental Disorder (22 September 2004) and Council of Europe Recommendation Rec. No. $R$ (99) of the Committee of Ministers to Member States on Principles Concerning the Legal Protection of Incapable Adults (23 February 1999). Arnete Erdmane has argued that the 'hard law' norms of the Council of Europe, including in particular the case law of the ECtHRs, does not always live up to the standards set out in these soft law instruments. A. Erdmane, 'Liberty behind closed doors ...? Involuntary placement and medical treatment in psychiatric institutions from the human rights perspective', Vienna Online Journal of International Constitutional Law 4(1) (2010) 90-146, 145. Lastly, the work of the European Committee on the Prevention of Torture has also addressed enforced treatment in psychiatric institutions. For reasons of space, that work is not considered here. For a brief 
ECHR, which prohibits 'inhuman or degrading treatment' and Article 8 of the ECHR, which protects the right to private and family life, to rule in a number of cases concerning informed consent. Moreover, the ECtHRs has frequently noted that the ECHR must be interpreted in light of 'present-day conditions. ${ }^{33}$ In the case of Demir and Baykara the Court observed that 'it has always referred to the "living" nature of the Convention, which must be interpreted in light of present-day conditions, and that it has taken account of evolving norms of national and international law in its interpretation of Convention provisions. ${ }^{34}$ It was sufficient for the Court that 'the relevant international instruments denote a continuous evolution in the norms and principles applied in international law... and show, in a precise area, that there is common ground in modern societies.' ${ }^{35}$ The Court's interpretation of ECHR provisions is therefore influenced by emerging international consensuses expressed through inter alia treaty law and it is clear that the wide-ranging, and widely ratified, CR PD is potentially relevant to many ECHR rights. This is already reflected in the many judgments in which the ECtHRs has referred to the CRPD. ${ }^{36}$

\subsection{Article 3-Prohibition of Inhuman and Degrading Treatment}

The ECtHRs has recognised that, in some circumstances, the imposition of medical treatment without the consent of a patient can amount to a breach of Article 3. Elizabeth Wicks has argued that " $\mathrm{t}$ ] he key to prohibited treatment under Article $3 \ldots$ appears to be the concept of human dignity rather than individual self-determination or autonomy' ${ }^{37}$

An important case addressing the involuntary treatment of a person with a psychosocial disability, which has been repeatedly cited by the Court, is Herczegfalvy v. Austria. ${ }^{38}$ The applicant in this case had served a number of

discussion on this issue see European Union Agency for Fundamental Rights, Involuntary placement and involuntary treatment of persons with mental health problems, supra note 5 . See e.g. Marckx v. Belgium (European Court of Human Rights, Chamber, Application No 6833/74, 13 June 1979) and Demir and Baykara v. Turkey (European Court of Human Rights, Grand Chamber, Application No 34503/97, 12 November 2008).

34 Ibid., para. 68.

35 Ibid., para. 86.

36 See, for example, Glor v. Switzerland (European Court of Human Rights, Chamber, Application No 13444/04, 30 April 2009) and, more recently, M.s. v. Croatia (No. 2) (European Court of Human Rights, Chamber, Application No 75450/12, 19 February 2015.

37 E. Wicks, 'The Right to Refuse Medical Treatment under the European Convention on Human Rights', Medical Law Review 9(1) (2001) 17-40, 22.

38 Herczegfalvy v. Austria (European Court of Human Rights, Chamber, Application No 10533/83, 24 September 1992). 
prison sentences following convictions for violent offences. In May 1977 a court ordered that the applicant should remain in detention after he had finished serving his sentence. This was done under the Austrian Code of Criminal Procedure and on the basis that there was a risk that the applicant might abscond and commit further offences. In November 1977 the applicant was declared partly incapacitated by a court on the basis of a psychiatrist's report and he was later placed in an institution for mentally ill offenders. In protest at his ongoing detention, the applicant began a hunger strike and became ill. $\mathrm{He}$ was then force fed, physically restrained by belts and straps, and given medication against his will. This went on for some time. The applicant argued before the ECtHRs that this treatment breached Article $3 .{ }^{39}$ In response the Court stressed that individuals detained in psychiatric hospitals are protected by Article $3 \mathrm{ECHR}$, and particular vigilance is required in protecting the rights of such individuals. The Court held:

The Court considers that the position of inferiority and powerlessness which is typical of patients confined in psychiatric hospitals calls for increased vigilance in reviewing whether the Convention has been complied with. While it is for the medical authorities to decide, on the basis of the recognised rules of medical science, on the therapeutic methods to be used, if necessary by force, to preserve the physical and mental health of patients who are entirely incapable of deciding for themselves and for whom they are therefore responsible, such patients nevertheless remain under the protection of Article 3 (art. 3) (sic), whose requirements permit of no derogation. ${ }^{40}$

The Court continued to hold 'as a general rule, a measure which is a therapeutic necessity cannot be regarded as inhuman or degrading. The Court must nevertheless satisfy itself that the medical necessity has been convincingly shown to exist'.41 In making this assessment the 'established principles of medicine' are to be regarded as 'decisive',42 although the Court did not elaborate on how to identify such 'established principles'. Applying this rule to the case at hand, the Court found the available evidence was 'not sufficient to disprove the Government's argument that, according to the psychiatric principles

He also asserted that it breached Article 8 ECHr. As with the Article 3 ECHR claim, the European Court of Human Rights found no violation of Article 8.

$40 \quad$ Supra note 38 , para. 82.

41 Ibid.

42 Ibid. 
generally accepted at the time, medical necessity justified the treatment in issue. ${ }^{43}$ As a consequence, no violation of Article 3 ECHR was found. ${ }^{44}$

This case has set the tone for subsequent Article 3 ECHR cases concerning involuntary treatment of people with psychosocial disabilities, and the case is also frequently cited by the Court in Article $8 \mathrm{ECHR}$ cases. Whilst the Court continues to hold that such individuals fall within the protection of Article $3,{ }^{45}$ it also indicates that it will defer to the medical authorities to decide on the appropriate form of treatment, which can be administered by force if necessary, 'to preserve the physical and mental health of patients who are entirely incapable of deciding for themselves'. ${ }^{4}$

Two requirements were set out for forced treatment to be compatible with Article 3 ECHR in Herczegfalvy. First, the treatment must be to preserve the physical and mental health of the patient. It seems the Court will be rather deferential to the medical authorities with regard to this assessment. Admittedly the ECtHRs stated in Herczegfalvy that it had to be satisfied that the treatment was medically necessary, but, in the case at hand, it found there was insufficient evidence to prove that this was not the case - thereby implying that the burden of proof shifts to the applicant (patient) to show that the treatment given was excessive or unnecessary, rather than requiring the government to establish its necessity. Arguably the Court is far less deferential to medical practitioners regarding assessments of the necessity of medical treatment in the case of individuals who are regarded as competent, and has been more willing to regard such treatment as a breach of Article $3 \cdot{ }^{47}$

43 Ibid., para. 83.

44 For criticism of the judgment in Herczegfalvy see Erdmane, supra note 32, 138-139.

45 For example, in Keenan v. United Kingdom (European Court of Human Rights, Chamber, Application No 27229/95, 3 April 2001) para. 113, the Court held: ' . . . in respect of a person deprived of his liberty, recourse to physical force which has not been made strictly necessary by his own conduct diminishes human dignity and is in principle an infringement of the right set forth in Article 3. Similarly, treatment of a mentally ill person may be incompatible with the standards imposed by Article 3 in the protection of fundamental human dignity, even though that person may not be able, or capable of, pointing to any specific ill-effects'. References omitted. In this case the Court found a breach inter alia of Article 3 after a prisoner with a psychosocial disability took his own life. The breach was not related to forced medication.

46 Herczegfalvy v. Austria, supra note 38 , para. 82.

47 A significant case in this respect is Jalloh v. Germany (European Court of Human Rights, Grand Chamber, Application No 54810/oo, 11 July 2006) in which the Court held that the forced administration of treatment which led to an individual regurgitating drugs which 
Secondly, the patient must be 'entirely incapable' of deciding whether to accept the treatment or not. In Herczegfalvy the Court did not examine whether the applicant was indeed 'entirely incapable' of making such decisions with regard to the alleged violation of Article 3, but, under another heading, found that the authorities have 'a certain discretion' when deciding whether a person is to be detained as 'of unsound mind'48 under Article 5(1 ${ }^{49}$ and held that the Austrian courts had not breached the ECHR when ordering the applicant's detention. Moreover, when considering the alleged breach of Article 8, the Court did note that it attached: 'decisive weight here to the lack of specific information capable of disproving the Government's opinion that the hospital authorities were entitled to regard the applicant's psychiatric illness as rendering him entirely incapable of taking decisions for himself. 50 Once again, it seems that the burden of proof was shifted to the applicant to establish that he had the capacity to consent or refuse treatment.

Two subsequent cases in which the Court (or the related former European Commission of Human Rights) repeated its statement in Herczegfalvy that 'a measure which is a therapeutic necessity cannot be regarded as inhuman or degrading' are Buckley v. United Kingdom ${ }^{51}$ and Wilkinson v. United Kingdom. ${ }^{52}$ Like Herczegfalvy, both cases concerned individuals detained in secure psychiatric hospitals following a criminal conviction. In Buckley the applicant's son was restrained and injected against his will. Shortly thereafter he collapsed and died. The Commission found there was no indication that the treatment provided was 'other than part of a therapeutic regime' and noted that the applicant's own medical expert had not criticised the hospital for negligent treatment. The Commission therefore regarded the treatment as 'therapeutic' and, even though it had been administered forcibly and may have contributed to the patient's death, it did not amount to 'inhuman or degrading treatment. ${ }^{53}$

In Wilkinson the applicant was diagnosed with a psychotic mental illness and administered anti-psychotic medication against his will. The doctors treating Wilkinson regarded him as unable to consent given his paranoia and

he has swallowed, done with the purpose of obtaining evidence, amounted to a breach of Article 3.

48 Ibid., para. 63 .

49 Which provides that '[e]veryone has the right to liberty and security of the person'.

50 Ibid., para. 86.

$5^{1}$ Buckley v. United Kingdom (European Commission of Human Rights, First Chamber, Application No 28323/95, 26 February 1997). Wilkinson v. United Kingdom (European Court of Human Rights, Chamber, Application No 14659/02, 28 February 2006).

Ibid. The Commission also found no violation of Article 8 ECHR. 
argued that the medication would benefit him. In response the applicant argued that such treatment breached Articles 3 and $8 \mathrm{ECHR}$ and that the treatment was not necessary - thereby addressing one of the requirements raised by the ECtHRs in Herczegfalvy. In response the Court held:

The Court recalls that 'medical necessity', in this context, is not limited to life-saving treatment. It can also cover treatment, such as anti-psychotic medication, imposed as part of a therapeutic regime. In addition, the decision as to what therapeutic methods are necessary is principally one for the national medical authorities: those authorities have a certain margin of appreciation in this respect since it is in the first place for them to evaluate the evidence in a particular case. The Court's task is to review under the Convention the decisions of those authorities. ${ }^{54}$

In response to the applicant's evidence that at least one doctor had had doubts as to the appropriateness of the treatment, the Court held:

The Court considers that in many areas of medicine, not least psychiatry, decisions as to treatment are complex matters of judgment. Medical experts can legitimately disagree and such disagreement is not, in itself, demonstrative of an absence of medical necessity for the relevant treatment. ${ }^{55}$

The Court concluded 'the evidence is not sufficient to show that the national authorities exceeded their margin of appreciation in diagnosing that there was a medical necessity for the treatment'.56

In Nevmerzhitsky v. Ukraine ${ }^{57}$ the Court applied the 'Herczegfalvy test' to a prisoner who seemingly did not lack capacity. The applicant was force fed whilst he was on a hunger strike and alleged this breached Article 3 . The Court reiterated that 'a measure which is of therapeutic necessity from the point of view of established principles of medicine cannot in principle be regarded as inhuman and degrading. The same can be said about force-feeding that is aimed at saving the life of a particular detainee who consciously refused to

54 Wilkinson v. United Kingdom, supra note 52, 20. References to case law omitted.

55 Ibid., 21.

56 Ibid.

57 Nevmerzhitsky v. Ukraine (European Court of Human Rights, Chamber, Application No 54825/oo, 5 April 2005). 
take food'.58 However, it did not stress that this rule only applied to individuals deemed unable to consent - it seemed sufficient that a detainee's life was at risk as a result of his hunger strike, even if the detainee had the capacity to agree or refuse to take nourishment or treatment. In this case the Court found that the 'necessity' of the force feeding had not been established, as the Government was unable to produce evidence showing medical justification for the action, and the applicant claimed that medical examinations had not been carried out prior to taking the decision to administer force feeding. As a result, the treatment administered was of such a 'severe character' that it amounted to torture..$^{59}$

A more recent case in which the Court found a breach of Article 3 ECHR, and in which it referred to the CRPD and, notably Concluding observations of the UN Committee on the Rights of Persons with Disabilities, is M.s. v. Croatia (No .2). ${ }^{60}$ In this case the applicant complained that, inter alia, her rights under Article 3 ECHR had been breached when she had been involuntarily detained in a psychiatric hospital and subjected to physical restraint for 15 hours following her admission. The Court did not cite Article 12 CR PD or General Comment No 1 as relevant international material, but rather regarded Articles 13 CRPD on access to justice and Article 14 CRPD on liberty of the person as relevant to the case at hand. However, these articles were not referred to in the substantive part of the judgment addressing the Article 3 complaint. In that part of the judgment the Court referred to the approach established in Herczegfalvy, and found that the physical restraint experienced by the applicant was capable of amounting to torture or unhuman or degrading treatment or punishment. Turning to the issue of justification, the Court considered whether the treatment was medically necessary. It recognised that such measures should be 'employed as a matter of last resort' ${ }^{61}$ and the use of such measures 'must be commensurate with adequate safeguards from any abuse.' 62 The Court noted that the applicant's medical records did not indicate that she was at immediate or imminent risk of harming herself at others at the time of the admission ${ }^{63}$ and that there was no evidence that alternative means of addressing 'her restlessness' had been tried or that the use of physical restrain was used as

\footnotetext{
$5^{8} \quad$ Ibid., para. 94.

$59 \quad$ Ibid., para. 98.

6 Supra note 36 .

$61 \quad$ Ibid., para. 104.

$62 \quad$ Ibid., para. 105.

63 Ibid., para. 106.
} 
a matter of last resort. ${ }^{64}$ The Court was also not satisfied that the applicant had been effectively and adequately monitored whilst under restraint. ${ }^{65}$ As a result the Court found that the Government had failed to show that the use of restrains was 'necessary and proportionate'66 and that Article 3 ECHR had been breached. It is hoped that this case is an indicator that the Court is willing to scrutinise more closely the medical necessity of involuntary psychiatric treatment in the future.

In conclusion, whilst the Court has recognised that involuntary medical treatment can amount to 'inhuman and degrading treatment', in general the case law demonstrates that individuals who are detained in secure psychiatric institutions who have been deemed unable to consent to medical care, or who can be subject to treatment for a 'mental disorder' under the terms of their detention, ${ }^{67}$ face great challenges if they are to establish that involuntary treatment breaches Article 3 ECHR. Such treatment will not breach Article 3 if it is found to be therapeutically necessary. This approach has been criticised since it does not take account of the fact that necessary treatment can be administered in a number of ways, some of which are more or less intrusive or restrictive. ${ }^{68}$ Electro-convulsive therapy, for example, can be administered under anaesthetic and with muscle relaxants, making it less likely to cause physical injuries to the patient than when no sedation is used. ${ }^{69}$ If the 'necessity' of the treatment is the only factor considered, then the Court will not examine whether the treatment was administered in a humane way or indeed, in accordance with the wishes of the patient, who may have been willing to consent to the treatment in one form, but not in another.

The case law also indicates that the Court is generally deferential to decisions of national authorities, taken in accordance with domestic law, that individuals can be subject to psychiatric treatment against their will, and is also highly deferential to the decisions of medical practitioners that such treatment has a therapeutic basis and is designed to benefit the patient. This has led Bartlett to comment that prohibitions based on 'torture or inhuman

\footnotetext{
64 Ibid., para. 108.

65 Ibid., para. 111.

66 Ibid., para. 110.

67 This was the case for both Mr. Buckley and Mr. Wilkinson under the Mental Health Act 1983 (UK).

68 Erdmane argues that this principle is reflected in Council of Europe soft law instruments, but is not applied by the European Court of Human Rights. Erdmane, supra note 32, 143-145.

$69 \quad$ Ibid., 140.
} 
or degrading treatment' have, in the context of people with psychosocial disabilities in Europe, 'been interpreted with astonishing deference to the medical profession, ${ }^{70}$ and that:

[i]n human rights terms, this is at best a peculiar starting point. It suggests that the factual basis of whether a basic human right has been violated will be determined by privileging the views of the alleged violator of the right. This cannot be a general principle of human rights law: we would not similarly defer to the views of alleged torturers in determining an article 3 violation. ${ }^{71}$

Anete Erdmane similarly argues ' $[\mathrm{t}]$ he Court is hesitant to scrutinise medical evidence in substance, and some authors deem that it would be unlikely that the Court would ever start to do so.' ${ }^{72}$ Erdmane also argues, based on analysis of case law, that the Court relies on medical reports, and 'is only verifying some procedural aspects of examinations.' ${ }^{73}$ In brief, the Court in general is reluctant to hold that the medical treatment provided is inappropriate or unnecessary, and adopts a very low level of scrutiny. It is too early to say if the recent case of M.s. v. Croatia (No. 2) heralds an intention to scrutinise more closely the decision of medical practitioners, and if the CRPD is influencing the Court's approach in this respect.

\subsection{Article 8-Right to Private Life}

A second route for individuals to challenge involuntary medical treatment is under Article 8 ECHR. In considering cases under this article the Court has stressed that 'even a minor interference with the physical integrity of an individual must be regarded as an interference with the right to respect for private life under Article 8 if it is carried out against the individual's will. ${ }^{74}$ Aart Hendriks argues that 'States have a positive obligation to make certain that physicians discuss the possible effects of a treatment with patients, and this in such a way that the requirement of informed consent is complied with. In the Court's opinion, failing to provide patients with adequate information harms

\footnotetext{
$70 \quad$ Bartlett, supra note 9,756 .

$71 \quad$ P. Bartlett, 'Capacity, Treatment and Human Rights', Journal of Mental Health Law (2004) $52-65,57$.

72 Erdmane, supra note 32, 110. Footnote omitted.

73 Ibid.

74 Storck v. Germany (European Court of Human Rights, Chamber, Application No 61603/oo, 16 June 2005).
} 
the self-determination of the person concerned and could constitute a violation of Article $8 \mathrm{ECHR}{ }^{75}$ The Court has also recognised that individuals have the right to refuse treatment, even if this treatment is seemingly in their best interest and has held 'the imposition of medical treatment without the consent of a mentally competent adult patient would interfere with his or her right to physical integrity and impinge on the rights protected under Article 8 of the Convention: ${ }^{76}$

Whilst Article 8 ECHR can be understood as embracing a prohibition of involuntary medical treatment in general, the article does allow for public authorities to interfere with the rights protected under the article where that interference is in accordance with the law, necessary in a democratic society and serves a legitimate interest, including the protection of health and the rights and freedoms of others. ${ }^{77}$ Cases concerning forced medical treatment have therefore often turned on the issue of whether the treatment fell within the exceptions set out in Article 8(2) ECHR, and was therefore permitted, or whether the treatment did not fall within the Article 8(2) ECHR exceptions.

Medical treatment which is provided against a patient's will must be provided in accordance with domestic law. In $X$. v. Finland ${ }^{78}$ the Court stressed that this means that the treatment must not only have some basis in domestic law, but 'also refers to the quality of the law in question, requiring that it should be accessible to the person concerned, who must moreover be able to foresee its consequences for him, and compatible with the rule of law'. ${ }^{79}$ The applicant in this case had been subject to forced detention and medication in a psychiatric hospital. The Court found that the measures had a basis in Finnish law, but that they nevertheless amounted to a breach of Article 8, because these actions were based on a law which lacked proper safeguards against arbitrariness. The decision to detain the applicant, which was taken by a court, included an 'automatic authorisation' forcibly to administer medicine if the applicant refused treatment, and this decision was the sole responsibility of doctors 'who

75 A. Hendriks, 'Council of Europe', in B. Toebes, A Hendriks and J.R. Hermann (eds.), Health and Human Rights in Europe (Cambridge: Intersentia, 2012), pp. 21-50, 37; referring to Testa v. Croatia (European Court of Human Rights, Chamber, Application No 20877/04, 12 July 2007) para. 52.

76 Ibid., p. 30; referring toJehovah's Witnesses of Moscow v. Russia (European Court of Human Rights, Chamber, Application No 302/02, 10 June 2010) para. 135. Italics inserted.

77 Article 8(2) ECHR.

78 X. v. Finland (European Court of Human Rights, Chamber, Application No 34806/04, 3 July 2012). A violation of Article 5(1) (right to liberty and security) was also found in this case.

$79 \quad$ Ibid., para. 6. 
could take even quite radical measures regardless of the applicant's wishes' ${ }^{80}$ Similarly, the Court found that the imposition of psychiatric treatment on an applicant for over five years amounted to a breach of Article 8 in Shopov v. Bulgaria. ${ }^{81}$ Whilst the treatment had a legal basis, the Court found that the regular judicial supervision which was required under the relevant legislation had not been provided, and this led to a violation of the Convention. The Court therefore views medical treatment imposed on patients without their consent as violating Article $8 \mathrm{ECHR}$ where there is an absence of appropriate legal protection and supervision.

The second (cumulative) requirement for permissible forced medical treatment is that the treatment must be necessary. This was at issue in the case of Glass v. United Kingdom, ${ }^{82}$ which involved a decision of medical authorities to provide treatment to a severely disabled child against the wishes of the mother, and without a court order. This case therefore did not concern a person with psychosocial disabilities, but a mother, who was regarded as competent, taking a decision on behalf of her child. The hospital believed the child was close to death and gave him powerful medicine which was designed to relieve his pain. The authorities had also placed a 'do not resuscitate' on the child's file. All of this was done against the mother's wishes. In spite of this treatment, the child recovered from this crisis and was allowed to return home. The Court found that the decision to impose treatment on the child (the second applicant in the case) in these circumstances had resulted in an interference with his right to respect for his private life and, in particular, his right to physical integrity. Whilst the Court found that this interference was in accordance with the law and pursued a legitimate aim, the Court did not regard the measure as necessary, since the authorities could have referred the question to a domestic court for a decision on the need for the treatment they favoured.

The third requirement, namely that the measure pursues a legitimate aim, was considered in Schneiter v. Switzerland, ${ }^{83}$ which concerned the use of forced medication in a psychiatric hospital. In this case the Court found that the applicant's complaint under Article 8 was ill-founded because the treatment had a legal basis and pursued the legitimate aim of protecting the rights

\footnotetext{
8 Ibid., para. 9 .

81 Shopov v. Bulgaria, (European Court of Human Rights, Chamber, Application No 17253/07, 16 April 2013). A violation of Article 5(1) ECHR was also found in this case.

82 Glass v. United Kingdom (European Court of Human Rights, Chamber, Application No 61827/oo, 9 March 2004).

83 Schneiter v. Switzerland (European Court of Human Rights, Chamber, Application No 63062/oo, 31 March 2005).
} 
and freedoms of others. In reaching this conclusion, the Court considered that the applicant had previously struck a nurse. This echoes the conclusions of Hendriks that '... the Court's case law shows that forced treatment can also be justified without this being in the interests of (the health of) the person concerned'. 84

Whilst the general position is that forced medical treatment will amount to an unjustified interference in an individual's private life under Article 8 ECHR, this rule seems to not apply in the case of patients who are deemed to be 'mentally incompetent'. If the domestic law provides for sufficient safeguards, including the review of treatment at appropriate intervals, and if the treatment is regarded as necessary and serving the legitimate aim of protecting the health of the patient or the rights and freedoms of others, such treatment can be imposed without consent. Indeed, the indications are that the Court has not always applied the 'justification' tests set out in Article 8(2) in such cases, regarding enforced treatment on 'incompetent patients' as compatible with the Convention as long as it is 'therapeutically necessary'. In this respect Hendriks, quoting many of the cases discussed under the section on Article 3 ECHR above, has noted ' $\mathrm{t}$ ] he Court is inclined to regard the failure to comply with the requirement of consent as justified when this involves "therapeutic necessity" for treatment, a criterion which the Court interprets broadly' ${ }^{85}$ More recently other scholars have argued that the Court has developed its case law in this respect:

[a]lthough the Court formerly considered that treatment without consent did not constitute an interference when the patient was not capable of giving consent, it now appears to accept that there will be an interference in such cases and that lack of capacity to consent is a matter pertinent to justification under Article 8(2). ${ }^{86}$

In general the assessment of capacity to consent is made by domestic courts on the advice of psychiatrists or other medical specialists. There is a risk that a perceived irrational or illogical refusal to give consent may in itself be taken as evidence of inability to give consent. ${ }^{87}$ The disadvantaged position of

84 Hendriks, supra note 75, 39; referring to Jalloh v. Germany (European Court of Human Rights, Grand Chamber, Application No 54810/oo, 11 July 2006) para. 70.

85 Hendriks, ibid., 39. Case law citations omitted.

86 D. Harris, M. O'Boyle, E. Bates and C. Buckley, Law of the European Convention on Human Rights, 3rd edition (Oxford: Oxford University Press, 2014) p. 544. Footnote omitted.

87 A point also made by Erdmane, supra note 32, 128. 
marginalised groups, and their vulnerability to torture and ill treatment, has been recognised by the un Special Rapporteur on Torture, who refers to ' $[\mathrm{s}]$ tructural inequalities, such as the power imbalance between doctors and patients, exacerbated by stigma and discrimination'. ${ }^{88}$ Such factors can also influence the identification of certain patients as unable to consent. In addition, courts may not feel equipped or inclined to question the assessment of members of the medical profession that an individual is unable to assess the benefits and risks of medical treatment, and consent to such treatment. However, as Wicks argues ' $[\mathrm{t}]$ he freedom to make one's own choices, which... is protected by Article 8, is only of value if the act of choosing is protected irrespective of the choice made. ${ }^{89}$ If the protection from involuntary treatment offered by the ECHR is rendered inapplicable in the case of individuals deemed unable to consent, and the ECtHRs is quick to accept the assessment of the medical profession and domestic courts regarding inability to consent, such individuals can be left in a very vulnerable position.

In contrast, in other fields the ECtHRs has recently shown a willingness to question the assessment of States regarding the ability of individuals to make decisions affecting their own life, and the consequences of denial of legal capacity. A prominent example of such a case is Alajos Kiss v. Hungary, ${ }^{90}$ which concerned the automatic disenfranchisement of the applicant, who had a psychosocial disability, following his consensual placement under partial guardianship. The Hungarian Government had argued that it was permissible for the legislature to establish rules ensuring that only those who are capable of assessing the consequences of their decisions and making conscious and judicious decisions should participate in public affairs, and that the disenfranchisement was compatible with the ECHR. Whilst the Court recognised that States would normally have a wide margin of appreciation in establishing who was entitled to vote, ${ }^{91}$ it held that an 'indiscriminate removal of voting rights, without an individualised judicial evaluation and solely based on a mental disability necessitating partial guardianship, cannot be considered compatible

88 J.E. Méndez, Report of the Special Rapporteur on torture and other cruel, inhuman and degrading treatment or punishment, HRC, 22nd sess, UN Doc A/HRC/22/53 (1 February 2013), para. xxvi-xxiv; cited by J. Cohen and T. Ezer, 'Human Rights in Patient Care: A Theoretical and Practical Framework', Health and Human Rights 15(2) (2013), 7-19, 8 (footnote 4).

89 Wicks, supra note $37,27$.

9o Alajos Kiss v. Hungary (European Court of Human Rights, Chamber, Application No 38832/06, 20 May 2010).

$91 \quad$ Ibid., para. 41. 
with the legitimate grounds for restricting the right to vote. ${ }^{92}$ The Court found that the impugned measure breached Article 3, Protocol 1 ECHR on the right to free elections. ${ }^{93}$ In reaching this decision the Court stated that it regarded persons with psychosocial disabilities ('the mentally disabled') $)^{94}$ as a 'particularly vulnerable group', 95 and referred to the 'considerable discrimination'96 which they have suffered in the past. The Court noted the relevance of the CRPD, including Article 12 on legal capacity, in its judgment. ${ }^{97}$ However, it is worth noting that this case involved an 'automatic disenfranchisement' following a guardianship order, with no assessment of individual capacity. The Court accepted that an individualised assessment could result in an individual losing the right to vote..$^{98}$ In cases concerning forced medical treatment there is, purportedly at least, such an individualised assessment, and this may partly explain the ECtHRs reluctance to question the legitimacy or procedures associated with the decision regarding competency to consent.

\subsection{Legitimacy of Substitute Decision-making by Guardians / Legal Representatives}

The law of most European states allows for a guardian or legal representative to consent to medical treatment on behalf of a person who is regarded as lacking legal capacity. ${ }^{99}$ The ECtHRs has not held that medical treatment which has been approved by a guardian, but objected to by an individual who has formally been denied legal capacity, breaches the Convention. ${ }^{100}$ However, the

$92 \quad$ Ibid., para. 44.

93 Article 3, Protocol 1 ECHR provides as follows: 'The High Contracting Parties undertake to hold free elections at reasonable intervals by secret ballot, under conditions which will ensure the free expression of the opinion of the people in the choice of the legislature.'

94 Supra note 90, para. 42.

95 Ibid.

96 Ibid.

97 Ibid., para. 14.

98 Ibid., para. 44.

99 See L. Waddington, Access to Healthcare by People with Disabilities in Europe - A Comparative Study of Legal Frameworks and Instruments, Synthesis Report for the Academic Network of European Disability Experts, (2014) 79-99 (Part 2, Section $2.1-$ Informed Consent for Medical Treatment). Available via: www.disability-europe.net/ content/access-healthcare.

100 Although the Court was invited to consider whether such treatment, which was given in a psychiatric hospital to which the applicant had been admitted with the consent of his guardian, breached Article 8 ECHR in Sýkora v. Czech Republic (European Court of Human Rights, Chamber, Application No 23419/07, 22 November 2012). This part of the application was however rejected on grounds of non-exhaustion of domestic remedies. 
Court has ruled in a number of cases in which individuals without legal capacity have been detained in psychiatric institutions, with the consent of their guardians, but in opposition to their wishes. Such cases have been based on Article 5(1) ECHR, which provides that '[e]veryone has the right to liberty and security of the person'.

In Shtukaturov v. Russia ${ }^{101}$ the Court examined the lawfulness of the detention in a psychiatric hospital of an adult who had been declared legally incompetent. Under Russian law the placement in the hospital was considered voluntary since the applicant's guardian had consented. As a result there was no need for a court order and the procedural safeguards applicable to a nonvoluntary detention did not apply. ${ }^{102}$ Nevertheless the applicant had indicated his resistance to the order declaring him incompetent and to his detention on repeated occasions, and had contacted a lawyer. The ECtHRs acknowledged that the applicant 'lacked de jure legal capacity to decide for himself'. However, it found that 'this does not necessarily mean that the applicant was de facto unable to understand his situation.' ${ }^{103}$ In conclusion the Court found a breach of Article 5(1) noting that it was 'unable to accept in the circumstances the Government's view that the applicant agreed to his continued stay in the hospital. ${ }^{104}$ Commenting on this case, Anete Erdmane has argued that the ECtHRs 'placed actual capacity above legal capacity' 105 and held that the applicant had been deprived of his liberty in a coercive manner, due to the fact that he did not give consent to the placement. She notes that the agreement of the guardian was not sufficient to recognise the placement as voluntary. A similar conclusion was reached in Stanev v. Bulgaria ${ }^{106}$ in which the Court held that because the applicant's institutionalisation was agreed to by his representative, but without the authorisation of the applicant, Bulgaria had violated the applicant's right to personal liberty under Article 5(1). ${ }^{107}$

It is possible to envisage a similar challenge to medical treatment which has been consented to by a guardian or legal representative, but objected to by an applicant, who has been formally denied legal capacity. In many States

\footnotetext{
101 Shtukaturov v. Russia (European Court of Human Rights, Chamber, Application No 44009/05, 27 March 2008).

102 Ibid., para. 102.

103 Ibid., para. 108.

104 Ibid., para. 109.

105 Erdmane, supra note 32, 122.

106 Stanev v. Bulgaria (European Court of Human Rights, Grand Chamber, Application No 3676o/o6, 17 January 2012).

107 See also Stanov v. Bulgaria (European Court of Human Rights, Chamber, Application No 25820/07, 17 March 2015) and Sýkora v. Czech Republic (European Court of Human Rights, Chamber, Application No 23419/07, 22 November 2012).
} 
the removal of legal capacity is complete, and does not take into account any (residual) ability an individual may have to decide on action or treatment in specific areas or to express preferences. ${ }^{108}$ However, such an 'all or nothing' approach often does not reflect the actual ability or capacity of individuals, and nor does it take into account that capacity may fluctuate over time. If the Court is not willing to scrutinise very closely such medical treatment, which may well be perceived as forced and non-consensual by patients, it risks leaving disadvantaged and excluded individuals in a very vulnerable position. Its recent case law on institutionalisation will hopefully be followed with regard to such cases, should they come before the ECtHRs. In any case, the Court seems to have indicated its intention to scrutinise compliance with the ECHR with regard to people with psychosocial disabilities by stating: 'any encroachment in the Convention rights of those belonging to particularly vulnerable groups such as psychiatric patients can be justified only by "very weighty reasons" (see Alajos Kiss), and the authorities should not lose sight of the importance of fully respecting the physical and personal integrity of such persons, in conformity with Article 8 of the Convention.'.09

\section{The Council of Europe Convention on Human Rights and Biomedicine}

In addition to the ECHR and related case law, the Council of Europe Convention on Human Rights and Biomedicine ${ }^{110}$ is relevant to the matter in hand. The European States which have ratified the Convention are to give effect to its provisions through domestic law, ${ }^{111}$ but, unlike the ECHR, the Convention is not backed up by a European court to which individuals can turn, and which

108 For examples in this respect see Waddington, supra note 99, 80-93 (Part 2, Section 2.1.1 The Law on Patient's Consent refers to Disabled Persons, or People Unable to Consent, or People without Legal Capacity).

109 Plesó v. Hungary (European Court of Human Rights, Chamber, Application No 41242/08, 2 October 2012) para. 65.

110 Convention for the Protection of Human Rights and Dignity of the Human Being with regard to the Application of Biology and Medicine: Convention on Human Rights and Biomedicine, Oviedo 4 April 1997. This Convention is also known as the Oviedo Convention. For a brief discussion on the relevance of the Oviedo Convention to involuntary treatment see European Union Agency for Fundamental Rights, supra note 5, at 25-26.

111 Article 1(2). See also E. Riedel, 'Global Responsibilities and Bioethics: Reflections on the Council of Europe's Bioethics Convention', 5 Global Legal Studies Journal (1997), 179-190 at 182. 
can identify breaches and require compliance. However, the ECtHRs can take the Convention into account in its judgments. The Convention addresses the need for informed consent for medical treatment. As a general rule, it provides that "[a]n intervention in the health field may only be carried out after the person concerned has given free and informed consent to it. This person shall beforehand be given appropriate information as to the purpose and nature of the intervention as well as on its consequences and risks. The person concerned may freely withdraw consent at any time. ${ }^{\prime 12}$ Article 6 of the Convention addresses the protection of persons who are not able to consent. Subject to some exceptions related to scientific research and organ and tissue removal from live donors, ${ }^{113}$ medical treatment can only be carried out on a person who is unable to consent where the treatment is for his or her direct benefit. ${ }^{114}$ The Convention provides:

Where, according to the law, an adult does not have the capacity to consent to an intervention because of a mental disability, a disease or for similar reasons, the intervention may only be carried out with the authorisation of his or her representative or an authority or a person or body provided by law.

The individual concerned shall as far as possible take part in the authorisation procedure. ${ }^{115}$

This authorisation may be withdrawn at any time in the best interests of the person concerned. ${ }^{116}$

The Convention provides that, subject to appropriate protective provisions which have been prescribed by law, 'a person who has a mental disorder of a serious nature may be subjected, without his or her consent, to an intervention aimed at treating his or her mental disorder'. However, this can only happen 'where, without such treatment, serious harm is likely to result to his or her health.'117

\footnotetext{
112 Article 5.

113 Article 20. In some circumstances an organ or tissue may be removed from a live donor who is unable to consent. A number of safeguards apply to individuals in this case, and this is only allowed if e.g. there is no compatible donor available who has the capacity to consent and the recipient is a brother or sister of the donor.

114 Article 6(1).

115 Article 6(3).

116 Article 6(5).

117 Article 7.
} 
In addition treatment can be carried out in 'an emergency situation' where consent cannot be obtained, and the intervention is necessary with a view to benefiting the health of the individual concerned. ${ }^{118}$ Lastly, the Convention provides that any previously expressed wish of a patient regarding treatment is to be taken into account in a situation in which the patient is not able to express his or her wishes at the time the treatment is to be provided. ${ }^{119}$ Eibe Riedel, writing in 1997, has argued that, with regard to consent, 'the Convention glossed over the underlying controversies. ${ }^{120}$ In brief, the Human Rights and Biomedicine Convention certainly allows for medical treatment without the consent of the patient in some situations, and as such is not compliant with the General Comment No 1 of the CRPD Committee on Article 12 which regards substitute decision-making, even when ostensibly done in the best interest of the patient, as a breach of the CRPD.

\section{5}

\section{Conclusion}

This article has explored how the European Convention on Human Rights, and related case law of the European Court of Human Rights apply to people with psychosocial disabilities and the right to informed consent for treatment and related detention. The case law indicates that while there has been some attention paid to human rights breaches in relation to processes surrounding detention, informed consent in itself has not been viewed as a pre-requisite for the treatment of people with psychosocial disabilities.

Whilst the ECHR has been interpreted as requiring informed consent for medical treatment in general, the ECtHRs has been willing to make an exception to this requirement for people with psychosocial disabilities. The case law demonstrates that the Court is fairly deferential to the decisions of medical practitioners regarding both the need for the treatment and the ability of the patient to consent. This is also reflected in the decisions of national courts which have heard the relevant cases previously. In recent years the ECtHRs has indicated that it will scrutinise particularly closely 'any encroachment on the rights of... psychiatric patients, ${ }^{121}$ but this does not seem to have been reflected in its judgments on informed consent to date. Nor has the CR PD had a noticeable impact in this area of case law. Eilionoir Flynn and Anna ArsteinKerslake argue that, to date, the Court has only been 'tinkering around the

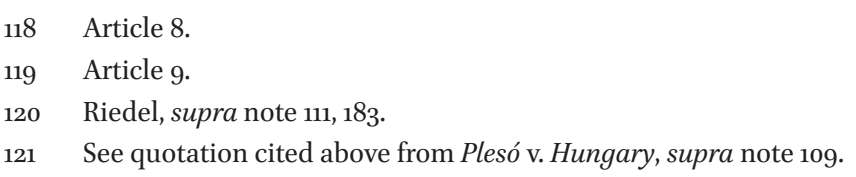


edges of violations related to legal capacity,'122 which includes the issue of consent to medical treatment. They argue that the Court could recognise the right to legal capacity on an equal basis as others by finding that a denial of legal capacity amounts to a violation of the prohibition against discrimination found in Article 14 ECHR. ${ }^{123}$ To date there is no evidence that the Court is moving towards such an approach, in spite of occasional references to the CRPD in its judgments.

In brief, only 'weak' protection has been afforded to people with psychosocial disabilities in relation to informed consent to medical treatment under the ECHR. This also seems to be the case under the Council of Europe Convention on Human Rights and Biomedicine which explicitly allows for substitute decision-making with regard to medical treatment in some cases.

In contrast stands the CRPD which, according to the CRPD Committee in its General Comment No 1 on Article 12, requires that medical treatment can only be given following the informed consent by persons with disabilities, including people with psychosocial disabilities. However, the approach to date in Europe indicates that it may prove difficult for the purist interpretation of the CRPD to have much traction, and existing case law presents barriers to the full acceptance of the rights set out in the CRPD by courts in relation to those with psychosocial disabilities. ${ }^{124}$

Whilst the CRPD may promise a 'new era', it may prove difficult to influence case law which is steeped in 'reading down' the rights of those with psychosocial disabilities. Nevertheless, whilst the ECtHRs may find itself unable to interpret the ECHR in the purist manner mandated by General Comment No 1, and this may also be the case for the practice of the Member States of the Council of Europe, it is submitted that the Court could still set higher levels of scrutiny and provide greater protection from unwanted medical treatment experienced by people with psychosocial disabilities in Europe.

122 Flynn and Arstein-Kerslake, supra note 30.

123 Ibid., 139-142. The Court declined to consider an Article 14 ECHR claim in the case of M.s. v. Croatia (No. 2 ) supra note 36 .

124 Stavert, supra note 27, also notes that the CRPD and ECHR 'adopt somewhat different approaches to the recognition and exercise of legal capacity' at 302. 